\title{
PENYULUHAN PENGUATAN SISTEM IMUN SEBAGAI PROTEKSI COVID-19 UNTUK GURU SMP NEGERI 1 PERAK JOMBANG
}

\author{
Ramadhany Hananto. P1, Hayati², Moh. Hanafi ${ }^{3}$, Bili Emir. R ${ }^{4}$, \\ Riga Mardhika5, I Gede Dharma. U6 \\ Pendidikan Jasmani Universitas PGRI Adi Buana Suarabaya \\ Email: ramadhany@unipasby.ac.id
}

\begin{tabular}{ll}
\hline Informasi Artikel & Abstrak \\
\hline Kata kunci: & Dalam rangka persiapan pembelajaran luring, SMPN 1 Perak Jombang \\
Covid 19, Penguatan & memerlukan banyak referensi tentang bagaimana meningkatkan sistem imun \\
sistem imun & di era pandemi agar terhindar dari covid-19. Dimulai dari pengetahuan tentang \\
& imun, maningkatkan imun dengan perbaikan nutrisi, meningkatkan imun \\
& dengan berolahraga dan pengetahuan lainnya yang dapat memberikan manfaat \\
& untuk semua. Maka dari itu, perlu diadakan penyuluhan tentang sistem imun \\
& di SMPN 1 Perak Jombang.
\end{tabular}

\footnotetext{
Abstact

In preparation for luring learning, junior high school perak jombang requires numerous feferences on how to increase the immune system in the pandemic to avoid the covid-19. Starting with knowledge of immunes, enhancing immunes with improved nitrion, increasing immunity by exercising and other vang knowledge can benefit all. Therefore, there needs to be some counseling additional autism immune system at junior high school perak jombang
} 


\section{PENDAHULUAN}

Pandemi adalah masa dimana kondisi yang tak pernah diharapkan oleh semua orang karena masa yang merebaknya suatu virus yang dinamakan covid 19 atau biasa disebut dengan istilah corona. Selama masa pandemi berlangsung semua masyarakat dihimbau untuk tidak keluar rumah jika memang tidak ada keperluaan yang sangat mendesak karena di khawatirkan jika masyarakat tetap di tempat-tempat umum penyebaran virus akan semakin mudah tertular apalagi mengingat virus ini sangat pesat penyebarannya melalui udara. Virus corona sendiri merupakan suatu virus berbahaya yang menyerang langsung pada kesehatan manusia yang bermula dengan gejala flu, batuk kering, demam, dan kelelahan hingga berujung pada kematian apabila tidak mendapatkan penindakan lebih lanjut. Virus ini berasal dari negeri seberang yang kita kenal sebagai negeri tirai bambu yaitu negara Cina, dimana virus ini pertama kali tercipta di kota Wuhan lalu negara-negara tetangga di Asia bahkan di Eropa dan juga sampai ke seluruh dunia terkena imbasnya.

Virus yang sudah tersebar dimana-mana ini menimbulkan berbagai keresahan yang terutama menyerang kesehatan kita semua, tidak sampai disitu corona juga membuat kondisi perekonomian negara manapun melemah, memakan banyak korban jiwa, hingga para pengusaha banyak yang gulung tikar karena minimnya pendapatan. Virus mematikan ini juga berdampak pada para pegawai atau karyawan baik di instansi maupun di perusahaan dengan terjadinya pengurangan karyawan besar-besaran yang mengakibatkan pemutusan hubungan kerja. Mereka semua terpaksa kehilangan mata pencahariannya untuk menghidupi keluarganya karena banyak instansi atau perusahaan yang mengalami kemerosotan pendapatan hingga kebangkrutan. Tak banyak dari mereka yang menerima dengan lapang dada atas keputusan yang merenggut mata pencaharian mereka, ada yang memilih diam di rumah dan ada juga yang tak terima hingga menggelar aksi unjuk rasa atau demo agar mereka tetap dipekerjakan kembali karena ada tanggungan yang harus mereka hidupi di saat kondisi yang juga perlu banyak asupan dana karena harus menjaga kesehatan.

Melihat dampak serius yang ditimbulkan oleh virus yang sampai sekarang belum mereda kita semua dihimbau untuk selalu menjaga kesehatan dan mentaati protokol kesehatan serta menggunakan masker agar kita terhindar dari virus yang mematikan serta kita dapat beraktivitas seperti sebelum datangnya virus ini. Dengan kita selalu menjaga kesehatan dan juga mentaati protokol kesehatan kita bisa memutus tali rantai penyebaran virus corona ini, adapun cara kita menjaga kesehatan dengan makan-makanan yang bergizi, mengonsumsi vitamin, rutin berolahraga dan juga menjaga kebersihan. Pemerintah sendiri sudah menerbitkan protocol kesehatan untuk mencegah penyebaran virus covid 19, sebagaimana yang tertuang dalam Surat Edaran Menteri Kesehatan Nomor HK.02.01/MENKES/335/2020 tentang Protokol Pencegahan Penularan Corona 

Virus Disease (Covid-19) di Tempat Kerja Sektor Jasa dan Perdagangan (Area Publik) dalam Mendukung Keberlangsungan Usaha. Upaya lain yang dilakukan oleh pemerintah untuk mencegah terjadinya penyebaran virus covid 19 yaitu dengan membuat budaya 3M (memakai masker, menjaga jarak, dan mencuci tangan) yang nantinya harus diterapkan oleh semua masyarakat untuk senantiasa menjaga kesehatan diri sendiri.

Menurut syarifuddin (2019), upaya untuk mengobati covid-19 adalah dengan meningkatkan sistem imun yaitu :tercukupinya nutrisi yang baik dan tambahan suplemen serta obat penunjang. Setidaknya imun memiliki 3 peranan penting dalam tubuh kita, yaitu : sebagai pertahanan, homeostatis dan perondaan. Fungsi pertahanan yang sudah diketahui sejak jaman dahulu, menyangkut pertahanan terhadap konfigurasi dari luar tubuh, terutama terhadap mikroba dan parasit yang akan menginvasi tubuh. Kemampuan mempertahankan diri, tergantung dari hasil perlawanan dengan patogen. Jika kemampuannya dapat mencegah invasi patogen dalam tubuh, maka tubuh tidak menderita sakit. Sebaliknya, jika invasi patogen dapat mengungguli sistem pertahanan tubuh, maka yang bersangkutan akan menderita sakit.

Dalam rangka persiapan pembelajaran luring, SMPN 1 Perak Jombang memerlukan banyak referensi tentang bagaimana meningkatkan sistem imun di era pandemi agar terhindar dari covid19. Dimulai dari pengetahuan tentang imun, maningkatkan imun dengan perbaikan nutrisi, meningkatkan imun dengan berolahraga dan pengetahuan lainnya yang dapat memberikan manfaat untuk semua. Maka dari itu, perlu diadakan penyuluhan tentang sistem imun di SMPN 1 Perak Jombang.

\section{METODE}

Untuk mencapai tujuan yang diharapkan, program pengabdian masyarakat di SMP Negeri 1 Perak- Jombang, dilakukan dengan pemberdayaan para guru melalui penyuluhan untuk selalu menjaga kondisi tubuh agar tetap sehat dengan menguatkan imun tubuh agar terhidar dan tidak tertular dari virus corona.

\begin{tabular}{|c|c|c|c|c|}
\hline No & Metode & Kegiatan & Durasi & $\begin{array}{c}\text { Jumlah Guru yang } \\
\text { terlibat }\end{array}$ \\
\hline 1. & Perizinan & $\begin{array}{l}\text { Meminta ijin kepeda kepala SMP N } 1 \\
\text { Perak Jombang untuk melaksanakan } \\
\text { kegiatan PPM }\end{array}$ & $1 \times 60^{\prime}$ & $\begin{array}{l}\text { Semua guru SMP N } 1 \\
\text { Perak Jombang }\end{array}$ \\
\hline 2. & $\begin{array}{l}\text { Edukasi Virus } \\
\text { Corona }\end{array}$ & Memberi wawasan terkait imunitas & $2 \times 120^{\prime}$ & $\begin{array}{l}\text { Semua guru SMP N } 1 \\
\text { Perak Jombang }\end{array}$ \\
\hline 3. & $\begin{array}{l}\text { Penyuluhan } \\
\text { sistem imun }\end{array}$ & $\begin{array}{l}\text { Memberikan penyuluhan peningkatan } \\
\text { sistem imun supaya tidak tertular virus } \\
\text { corona }\end{array}$ & $2 \times 120^{\prime}$ & $\begin{array}{l}\text { Semua guru SMP N } 1 \\
\text { Perak Jombang }\end{array}$ \\
\hline
\end{tabular}




\section{HASIL DAN PEMBAHASAN}

Pada kondisi pandemi saat ini, masyarakat terutama para pendidik/ guru membutuhkan banyak pengetahuan mengenai kesehatan diri dan penambahan ilmu pengetahuan tentang virus corona yang akan disalurkan kepada muridnya. Maka dari itu dari hal tersebut dapat diputuskan bahwa terdapat beberapa materi dari kegiatan PPM yang dapat dilakukan di SMP Negeri 1 Perak Jombang guna meningkatkan dan memberikan banyak pengetahuan, baik dari kesehatan maupun pendidikan. Terdapat beberapa meteri yang dilakukan oleh dosen, yaitu, edukasi tentang Covid 19 dan penguatan sistem imun. Materi utama kegiatan PPM ini adalah penyuluhan penguatan sistem imun sebagai proteksi covid-19 guru SMPN 1 Perak Jombang.

Sistem imun adalah sistem daya tahan tubuh terhadap segala bentuk serangan benda asing yang masuk kedalam tubuh. Benda asing tersebut bisa datang dari luar maupun dalam tubuh kita. Contoh benda asing yang berasal dari luar tubuh misalnya bakteri, virus, parasit, jamur, debu dan serbuk sari. Sedangkan benda asing dari dalam tubuh dapat berupa sel-sel mati atau sel-sel yang bermutasi bentuk dan fungsinya. Benda asing itu disebut imunogen atau antigen. Era pandemi saat ini, peran imun sangat dominan untuk mencegah virus covid-19 yang sedang mengintai setiap manusia. Dengan diperkuat sistem imun, diharapkan semua benda asing yang masuk ke dalam tubuh kita akan dikalahkan oleh imun yang ada di dalam tubuh.

Faktor yang mempengaruhi sistem imun adalah sebagai berikut:

1. Lingkungan

Lingkungan adalah faktor terbesar dan faktor yang sangat penting, karena dari lingkung kita melakukan kegiatan sehari-hari yang tidak bisa dikontrol. Lingkungan memiliki peran yang penting terhadap sistem imun, terlebih lagi yang berhubungan langsung terhadap pertahanan tubuh

2. Makanan

Makanan banyak mengandung lemak dan gula lebih beresiko menyebabkan stress pada sistem imun kita, sehingga mudah mengalami kerusakan dan mempermudah penyakit masuk kedalam tubuh kita. Makanan dengan kandungan lemak dan gula akan produksi proteinprotein yang menyebabkan kondisi stress pada tubuh.

3. Usia

Seperti sel pada umumnya, sel-sel imun juga berada pada titik tertinggi aktivitas ketika individu mencapai usia dewasa. Setelah itu semakin tua usia sel-sel ini akan menurun aktivitasnya, termasuk dalam produksi protein yang berfungsi untuk melawan virus, yaitu interferon.

4. Keadaan kesehatan

Individu yang memiliki penyakit terutama penyakit yang bersifat kronis akan lebih mudah virus untuk menginfeksi tubuh.

5. Konsumsi obat-obatan

Menurunnya kemampuan sistem imun dalam mempertahankan diri dapat dipengaruhi oleh beberapa obat-obatan, seperti kortison, hidrokortison. Pemakaian obat-batan ini dalam jangka waktu panjang sangat mungkin menurunkan kekebalan tubuh kita. 
berkolaborasi dengan sistem imun dan berakibat meningkatkan zat yang merangsang sistem kekebalan atau menekan semua obat yang dapat memodifikasi sistem imun. Pada dewasa ini berlimpahnya vitamin maupun obat herbal dari alam yang tersedia dan dijual bebas diklaim memiliki efek imunostimulan. Contoh yang dapat digunakan sebagai imunostimulator adalah : vitamin C, vitamin D, vitamin E, Zinc, selenium, herbal echinacea , propolis (lem lebah dalam pembuatan sarang), kerkumin (empon-empon), meniran

\section{KESIMPULAN}

Kegiatan PPM dalam memberdayakan Bapak Ibu guru untuk aktivitas yang dapat dilakukan dalam era pandemi telah berjalan dengan baik, dimana tingkat partisipasi bapak ibu guru sangat antusias untuk dapat mengikuti penyuluhan dan kegiatan lainnya. Bapak ibu guru memahami cara menghentikan penularan virus corona dengan menjaga kesehatan dengan cara meningkatkan sistem imun untuk menghidari tertular virus corona.

\section{UCAPAN TERIMAKASIH}

Jika perlu berterima kasih kepada pihak terlibat, misalnya sponsor pengabdian masyarakat dan semua pihak yang membantu dan tidak bisa disebut satu per satu. 


\section{DAFTAR PUSTAKA}

Edaran Menteri Kesehatan Nomor HK.02.01/MENKES/335/2020 tentang Protokol Pencegahan Penularan Corona Virus Disease (Covid-19) di Tempat Kerja Sektor Jasa dan Perdagangan (Area Publik) dalam Mendukung Keberlangsungan Usaha

Sasmito, E., 2017, Imunomodulator Bahan Alami, Penerbit Andi.

Sasmito, E., Sahid, M.N.A., dan Ikawati, M. (2020), Buku Petunjuk Praktikum Imunologi Farmaswi, Fakultas Farmasi UGM.

Syarifuddin. 2019. Imunologi Dasar: Prinsip Dasar Kekebalan Tubuh. Cendekia Publiser. Jakarta www.farmasi.ugm.ac.id . diakses 25 desember 2020. 